\title{
Strategi Bisnis UMKM Suka Maju untuk Meningkatkan Produktivitas dan Pendapatan selama Masa Pandemi
}

\author{
Viviani* $^{* 1}$, Lindawati ${ }^{2}$ Joey $^{3}$, Jovianto ${ }^{4}$ \\ 1,2,3,4 Manajemen, Fakultas Ekonomi, Universitas Internasional Batam, Indonesia \\ Email: 12041119.viviani@uib.edu, 22041118.lindawati@uib.edu, ${ }^{3} 2041163 . j o e y @ u i b . e d u$, \\ 42041276.jovianto@uib.edu
}

\begin{abstract}
Abstrak
Usaha Mikro Kecil Menengah adalah pihak yang memiliki andil yang sangat besar dalam perekonomian nasional. UMKM Suka Maju didirikan oleh Bapak Amat Pento pada tahun 1952 beralamatkan di Jalan R. A. Kartini 86, Tanjung Batu Kota, Kecamatan Kundur, Kabupaten Karimun, Kepulauan Riau. Produk yang ditawarkan berupa nasi dengan lauk pauk masakan padang seperti ayam gulai, ayam rendang, daging sapi, telur gulai, ikan, sayur nangka, dan sebagainya. UMKM Suka Maju dihadapkan oleh permasalahan perhambatan pada produktivitas bisnis yaitu pemesanan makanan yang hanya diperbolehkan take away dan juga pemesanan melalui aplikasi Kundur Food Delivery (KFD) selama masa pandemi. Tujuan dari penelitian ini adalah untuk mengetahui proses bisnis yang diterapkan, permasalahan yang dihadapi, analisis penyelesaian masalah, dan juga kebijakan untuk solusi produktivitas serta hasil pendapatan yang diperoleh UMKM Suka Maju selama masa pandemi. Dalam penelitian ini juga menggunakan metode penelitian pengumpulan data primer yaitu data dikumpulkan secara langsung dari sumber utama dan juga data sekunder yaitu data yang dikumpulkan secara tidak langsung atau dari sumber lain. Hasil penelitian menyimpulkan UMKM Suka Maju telah menerapkan tahapan proses bisnis sehingga berdampak positif terhadap operasional UMKM.
\end{abstract}

Kata kunci: Kebijakan, Permasalahan, Produktivitas, UMKM Suka Maju

\begin{abstract}
Micro, Small and Medium Enterprises are parties that have a very large share in the national economy. MSME Suka Maju was founded by Mr. Amat Pento in 1952, having his address at Jalan R. A. Kartini 86, Tanjung Batu City, Kundur District, Karimun Regency, Riau Islands. The products offered are rice with side dishes from Padang dishes such as curry chicken, chicken rendang, beef, curry eggs, fish, jackfruit vegetables, and so on. UMKM Suka Maju are faced with the problem of obstacles to business productivity, namely ordering food which is only allowed to take away and also ordering through the Kundur Food Delivery (KFD) application during the pandemic. The purpose of this research is to find out the business processes that are applied, the problems encountered, analysis of problem solving, and also policies for productivity solutions and the income results obtained by UMKM Suka Maju during the pandemic. This research also uses primary data collection research methods, namely data collected directly from the main source and secondary data, namely data collected indirectly or from other sources. The results of the study concluded that the UMKM Suka Maju had implemented the stages of the business process so that it had a positive impact on the operations of the UMKM.
\end{abstract}

Keywords: Policy, Problems, Productivity, UMKM Suka Maju

\section{PENDAHULUAN}

Usaha Mikro Kecil Menengah adalah pihak yang memiliki andil yang sangat besar dalam perekonomian nasional. Usaha mikro, kecil, dan menengah (UMKM) menjadi sektor yang terkena dampak cukup besar pada masa pandemi COVID-19 (Sularsih \& Nasir, 2021). Di masa pandemi COVID-19 UMKM memerlukan strategi usaha untuk dapat terus mempertahankan bisnisnya dalam upaya peningkatan pendapatan di tengah pandemi ini guna mempertahankan kelangsungan UMKM. UMKM berpotensi menjadi sumber pendapatan utama bagi sebagian besar masyarakat dengan mendorong kegiatan ekonomi dan meningkatkan kesejahteraan masyarakat (Inayah, 2019). 
UMKM Suka Maju didirikan oleh Bapak Amat Pento pada tahun 1952 beralamatkan di Jalan R. A Kartini 86, Tanjung Batu Kota, Kecamatan Kundur, Kabupaten Karimun, Kepulauan Riau. Pada saat itu juga Bapak Amat Pento merantau ke Tanjung Batu, beliau hanya memeliki keunggulan dalam memasak, sehingga beliau menjual makanan nasi padang untuk memenuhi kebutuhan keluarganya. Kemudian Bapak Amat Pento membangun UMKM untuk melanjutkan usahanya yang dinamakan "Suka Maju", alasan terlahirnya nama tersebut karena Bapak Amat Pento ingin usahanya selalu maju. Produk yang ditawarkan berupa nasi dengan lauk pauk seperti ayam goreng cabe, ayam goreng bumbu, ayam pangggang, ayam gulai, ikan, daging sapi, telur gulai, telur dadar, sayur nangka, dan sayur ubi. Tentunya beserta nasi yang dapat dijual secara terpisah.

UMKM Suka Maju juga menawarkan layanan dan fasilitas yang nyaman sebagai tempat bersantai, tetapi karena pandemi COVID-19 ada beberapa saat yang tidak bisa makan di tempat sehingga hanya dapat take away. Pelanggan juga bisa memesan makanan melalui aplikasi Kundur Food Delivery (KFD), tetapi menu makanan pada aplikasi belum terdapat banyak pilihan makanan. Sehingga pelanggan harus datang langsung ke toko untuk memilih menu yang belum terdapat pada aplikasi. Selain itu, UMKM Suka Maju belum melakukan promosi di sosial media, mengingat masa kini sosial media merupakan salah satu platform yang banyak digunakan dan juga cara promosi yang diterima baik dalam masyarakat.

Oleh karena itu, sesuai fenomena masalah yang dihadapi ini maka penulis ingin mengetahui lebih lanjut terhadap permasalahan dan kebijakan yang dirancang UMKM Suka Maju yang mempunyai hambatan dalam produktivitas dan hasil pendapatan selama masa pandemi COVID-19.

Tujuan dari penilitian ini adalah untuk mengetahui proses bisnis yang diterapkan, permasalahan yang dihadapi, analisis penyelesaian masalah, dan juga kebijakan untuk solusi produktivitas serta hasil pendapatan yang diperoleh UMKM Suka Maju selama masa pandemi.

\section{METODE PENELITIAN}

Dalam pelaksanaan penelitian, peneliti menggunakan data primer dan data sekunder. Data primer adalah sejenis data yang didapatkan oleh seorang peneliti secara langsung dari sumber utama yang dimana data-data yang didapatkan dari akan digunakan untuk menganalisis produktivitas dan pendapatan UMKM Suka Maju. Sedangkan, data sekunder merupakan data yang didapat dari sumber lain, dimana data-data diperoleh dari berbagai artikel maupun jurnal mengenai analisis produktivitas dan pendapatan UMKM Suka Maju. Penelitian ini memakai metode deskriptif kualitatif dengan tujuan untuk mengetahui dan menjelaskan suatu permasalahan dari hasil analisis.

\subsection{Penelitian Proses Bisnis UMKM Suka Maju}

Proses bisnis yang diterapkan UMKM Suka Maju selama pandemi COVID-19, antara lain:

1. Perencanaan

Pertumbuhan ekonomi juga merupakan kegiatan peningkatan pendapatan yang tidak terkait dengan pertumbuhan penduduk. Selama pandemi COVID-19, kebanyakan penjual dan pelanggan lebih memilih menjual dan membeli makanan dengan take away ataupun menjual dan membeli makanan melalui aplikasi, karena melalui aplikasi dapat memudahkan penjual dan pelanggan tanpa harus secara langsung pergi ke toko untuk membeli makanan ataupun minuman, serta bisa mematuhi protokol dengan tidak berkerumunan. Mengingat selama pandemi, Tanjung Batu Kundur membuat sebuah aplikasi baru untuk mengantar jemput makanan yang tentunya memudahkan penjual dan pelanggan dalam menjual dan membeli makanan maupun minuman. Maka dari itu, UMKM Suka Maju mempunyai rencana agar pelanggan merasa lebih nyaman dan dipermudah dengan memasarkan makanan melalui aplikasi Kundur Food Delivery (KFD), dengan begini pelanggan masih tetap bisa menikmati makanan dari UMKM Suka Maju di tengah pandemi tanpa harus mengunjungi UMKM Suka Maju secara langsung.

2. Produksi

Produksi yang dilakukan UMKM Suka Maju masih sama seperti sebelum mengalami masa pandemi COVID-19, yaitu dengan menggunakan seluruh bahan baku yang berkualitas tinggi, serta meningkatkan kesterilan dalam mengolah makanan dan minuman yang dijual. Dengan adanya bahan baku yang diproduksi semakin diperketat, maka pelanggan bisa menikmati makanan dan minuman dengan kualitas yang terjaga. 


\section{Pelaksanaan}

UMKM Suka Maju telah melaksanakan seluruh tahapan perencanaan dan produksi dengan upaya yang baik. Hal ini dibuktikan dengan beberapa kegiatan yang telah dijalankan seperti pemesanan makanan hanya diperbolehkan take away, memasarkan makanan melalui aplikasi Kundur Food Delivery (KFD) agar memudahkan pelanggan dan menghindari terjadinya kerumunan, menjaga kebersihan makanan, minuman dan lingkungan UMKM, serta kesehatan pekerja yang juga harus diutamakan.

4. Pemasaran

Permintaan akan barang dan jasa berdampak pada UMKM tidak dapat berfungsi optimum yang berujung pada berkurangnya likuiditas UMKM sehingga UMKM melakukan penjualan produk secara online adalah salah satu metode yang baik untuk memasarkan produk UMKM di Indonesia, karena metode ini dianggap mengalami peningkatan cukup pesat dari tahun ke tahun. E-commerce juga merupakan salah satu platform yang memiliki pengaruh positif dan signifikan terhadap pemasaran secara online (Hanum \& Sinarasri, 2017). Peningkatan kinerja UMKM.Semenjak adanya pandemi COVID-19, UMKM Suka Maju terdapat hambatan yang mempengaruhi pendapatan akibat produktivitas yang berubah. Sehingga, UMKM Suka Maju melakukan upaya strategi marketing agar tetap menstabilkan pendapatan di tengah pandemi. Adapun yang dilakukan UMKM Suka Maju, yaitu memasarkan makanan melalui aplikasi Kundur Food Delivery (KFD).

\section{Evaluasi}

UMKM Suka Maju diketahui telah menerapkan seluruh tahapan proses bisnis yang direncanakan dengan baik. Peningkatan kualitas produk dan kualitas layanan yang positif dan signifikan dalam membentuk kepuasan konsumen dan menciptakan konsumen loyalitas bagi pelaku UMKM juga dapat mempengaruhi perubahan dalam kegiatan operasional UMKM Suka Maju selama pandemi COVID-19, serta juga berdampak positif bagi perkembangan dalam produktivitas UMKM Suka Maju dan adanya peningkatan dalam pendapatan yang diperoleh dari hasil penjualan makanan dan minuman selama pandemi COVID-19.

\subsection{Permasalahan Bisnis UMKM Suka Maju}

Berdasarkan seluruh tahapan proses bisnis yang diterapkan oleh UMKM Suka Maju di tengah masa pandemi COVID-19, maka dapat diketahui bahwa UMKM Suka Maju mengalami permasalahan pada bisnisnya, yaitu adanya keterhambatan pada produktivitas. Produktivitas merupakan perbandingan antara keluaran (result) dan masukan (input). Keterhambatan produktivitasnya meliputi pemesanan makanan yang hanya diperbolehkan take away, ketersediaan makanan di aplikasi Kundur Food Delivery (KFD) masih belum lengkap sehingga pelanggan yang ingin menikmati makanan lain yang tidak tersedia di aplikasi tersebut harus secara langsung mengunjungi UMKM Suka Maju untuk bisa menikmatinya makanan tersebut, UMKM tersebut semakin diperketat dalam menjaga kebersihan makanan, minuman dan lingkungan UMKM, serta kesehatan pekerja yang juga harus diutamakan, serta UMKM Suka Maju masih belum mempunyai Sosial Media yang bisa memudahkan pelanggan dalam menghubungi UMKM tersebut. Maka dari itu, perlu adanya dorongan dalam UMKM Suka Maju untuk melakukan perubahan dalam strategi, mulai dari pengelolaan hingga penjualan makanan dan minuman. Selain itu, produktivitas UMKM Suka Maju yang terhambat ini sangat berpengaruh terhadap pendapatan yang dihasilkan. Hal ini tentu saja menjadi ancaman bagi UMKM Suka Maju apabila permasalahan dalam bisnisnya tidak dilakukan pencegahan dan penyelesaian dengan baik, karena dapat menimbulkan beragam kerugian pada UMKM tersebut dan juga akan berdampak bagi karyawannya.

\section{HASIL DAN PEMBAHASAN}

Dalam mengatasi berbagai masalah yang dihadapi UMKM Suka Maju Diketahui, melakukan beberapa perubahan strategis yang dilakukan di tahapan proses bisnis dapat membuahkan hasil yang cenderung berdampak positif terhadap produktivitas kegiatan bisnis selama pandemi COVID-19. Hal ini dapat dilihat dari penyesuaian peraturan dari Pemerintah Indonesia dan Pemerintah Daerah Tanjung Batu Kundur pada peraturan UMKM Suka Maju.

Pada masa pandemi COVID-19 ini, para karyawan UMKM Suka Maju juga menerapkan berbagai peraturan untuk menyesuaikan peraturan baru dari Pemerintah Indonesia dan Pemerintah Daerah 
Tanjung Batu Kundur. Berbagai perubahan peraturan juga bukan merupakan hal mudah bagi para karyawan. Tetapi semangat dari para karyawan dalam menghadapi perubahan peraturan ini sehingga UMKM Suka Maju bisa menghadapi permasalahan selama pandemi COVID-19 ini.

Selain itu, untuk permasalahan pemasaran makanan UMKM Suka Maju memanfaatkan aplikasi antar jemput makanan seperti Kundur Food Delivery (KFD) agar pelanggan dapat menikmati makanan tanpa harus membeli ke toko secara langsung mengingat selama pandemi COVID-19 para masyarakat harus menghindari kerumunan serta mematuhi protokol kesehatan dari Pemerintah. Melalui aplikasi KFD pelanggan dapat menikmati berbagai varian makanan yang ditawarkan oleh UMKM Suka Maju. Selain pemasaran melalui aplikasi KFD, UMKM Suka Maju juga bisa memasarkan produknya melalui sosial media mengingat teknologi yang sekarang sangat canggih dan rata-rata masyarakat sekarang juga banyak yang menggunakan sosial media maka UMKM Suka Maju bisa menargetkan social media sebagai salah satu pemasaran produknya.

Seluruh proses perencanaan perubahan dalam mengatasi produktivitas dan hasil pendapatan UMKM Suka Maju diketahui telah melakukan perubahan dalam strategi sehingga permasalahan UMKM dapat terselesaikan yang sesuai dan tepat dengan kebijakan yang sesuai masalah yang dihadapi UMKM. Kebijakan merupakan Tindakan yang akan diterapkan oleh seseorang atau sekelompok pelaku dalam memecahkan masalahnya. Maka UMKM Suka Maju menerapkan kebijakan yang berupa kebijakan patuh protokol kesehatan, kebijakan kinerja karyawan, dan juga kebijakan operasional usaha. Kebijakan diatas merupakan kebijakan yang sesuai dengan masalah yang tengah dihadapi oleh UMKM. Kebijakan protokol kesehatan untuk mengatasi masalah penyesuaian perubahan peraturan Pemerintah Indonesia dan Pemerintah Daerah Tanjung Batu Kundur dalam masa pandemi ini. Kebijakan Kinerja Karyawan untuk mengatasi permasalahan untuk mendorong karyawan dalam penyesuaian sikap kerja karyawan. Kebijakan operasional usaha untuk mendukung UMKM Suka Maju dalam pencapaian kestabilan produktivitas dan hasil pendapatan penjualan produk UMKM selama pandemi COVID-19.

\section{KESIMPULAN}

Berdasarkan hasil analisa yang dilakukan, maka dapat diketahui permasalahan pada UMKM Suka Maju selama pandemi COVID-19 ini, yaitu pemesanan makanan yang hanya diperbolehkan take away, ketersediaan makanan di aplikasi Kundur Food Delivery (KFD) masih belum lengkap sehingga pelanggan yang ingin menikmati makanan lain yang tidak tersedia di aplikasi tersebut harus secara langsung mengunjungi UMKM Suka Maju untuk bisa menikmatinya makanan tersebut, UMKM tersebut semakin diperketat dalam menjaga kebersihan makanan, minuman dan lingkungan UMKM, serta kesehatan pekerja yang juga harus diutamakan, serta UMKM Suka Maju masih belum mempunyai Sosial Media yang bisa memudahkan pelanggan dalam menghubungi UMKM tersebut. Selain itu, UMKM Suka Maju ini juga mengalami penurunan pada penjualan yang dikarenakan COVID-19 sehingga UMKM ini memasarkan makanannya melalui aplikasi yang bernama Kundur Foods Delivery (KFD). Pada tahap evaluasi UMKM Suka Maju diketahui telah menerapkan seluruh tahapan proses bisnis yang direncanakan dengan baik sehingga kegiatan operasional UMKM ini berdampak positif bagi perkembangannya dalam produktivitas dan adanya peningkatan dalam pendapatan yang diperoleh dari hasil jualan makanan dan minuman selama pandemi COVID-19.

\section{DAFTAR PUSTAKA}

Hanum, A. N., \& Sinarasri, A. (2017). Analisis Faktor-Faktor Yang Mempengaruhi Adopsi ECommerce dan Pengaruh Terhadap Kinerja UMKM. Maksimum Media Akuntansi Universitas Muhammadiyah Semarang, 8(1), 1-15.

Inayah. (2019). Kesadaran Hukum Pelaku Usaha Mikro Kecil Menengah (UMKM) dalam Perlindungan Kekayaan Intelektual. 4(2), 120-136.

Sularsih, H., \& Nasir, A. (2021). Strategi UMKM dalam meningkatkan pendapatan dimasa pandemi COVID-19 guna mempertahankan kelangsungan usaha di era revolusi industri 4.0 (studi pada UMKM makanan dan minuman di Kabupaten Pasuruan). Jurnal Paradigma Ekonomika, 16(4), $763-772$. 